\title{
Nutrient Management in Organic Greenhouse Herb Production: Where Are We Now?
}

\author{
Danielle D. Treadwell ${ }^{1,8}$, George J. Hochmuth ${ }^{2}$, \\ Robert C. Hochmuth ${ }^{3}$, Eric H. Simonne ${ }^{1}$, Lei L. Davis ${ }^{3}$, \\ Wanda L. Laughlin ${ }^{3}$, Yuncong Li ${ }^{4}$, Teresa Olczyk ${ }^{5}$, \\ Richard K. Sprenkel ${ }^{6}$, and Lance S. Osborne ${ }^{7}$
}

\begin{abstract}
AdDITIONAL INDEX wORDs. nitrogen, potting media, compost, basil,
\end{abstract} Ocimum basilicum, transplants

Summary. Consumer demand for fresh market organic produce combined with the increasing market share of ready-to-eat products indicates the potential for expansion of an organic culinary herb market. Barriers to organic herb greenhouse production are high as a result of lack of available technical information and the low number of producers experienced in this area. There is a critical need for information and technologies to improve the management of organic soil and fertilizer amendments to optimize crop yields and quality, manage production costs, and minimize the risk from groundwater nitrogen $(\mathrm{N})$ contamination. Because of limited information specific to organic culinary herb production, literature on organic vegetable transplants and conventional basil (Ocimum basilicum) production was also considered in this review. Managing $\mathbf{N}$ for organic crops is problematic as a result of the challenge of synchronizing mineralization from organic fertilizer sources with crop $\mathrm{N}$ demand. A combination of materials, including locally formulated composts, supplemented with standardized commercially formulated fertilizer products is one method to ensure crops have access to mineral $\mathbf{N}$ throughout their development. In experimental greenhouse systems, local raw materials are frequently used as media amendments to satisfy partial or complete crop fertility requirements. This makes comparisons among experiments difficult as a result of the wide variety of raw materials used and the frequent interactions of fertilizer source and planting media on nutrient availability. Nitrogen mineralization rates are also influenced by additional factors such as the environmental conditions in the greenhouse and physical and chemical properties of the media and fertilizer. Despite the variability within and among experimental trials, yields and quality of organically grown crops are frequently similar to, and occasionally better than, conventionally grown crops.

This research was supported by a grant from the USDA Cooperative State Research Education and Extension Service-TSTAR, Grant Nos. 00005923 and 00063651 .

${ }^{1}$ Department of Horticultural Sciences, University of Florida, P.O. Box 110690, Gainesville, FL 326110690

${ }^{2}$ Florida Agricultural Experiment Station, University of Florida, 1022 McCarty Hall, P.O. Box 110200 , Gainesville, FL 32611-0200

${ }^{3}$ North Florida Research and Education Center (NFREC)-Suwannee Valley, University of Florida, 7580 County Road 136, Live Oak, FL 32060

${ }^{4}$ Soil and Water Science Department, Tropical Research and Education Center, University of Florida, 18905 SW 280 Street, Homestead, FL 33031

${ }^{5}$ Ag./Vegetables, Miami-Dade County Extension Service, University of Florida, 18710 SW 288 Street, Homestead, FL 33030-2309

${ }^{6}$ NFREC, Department of Entomology and Nematology, University of Florida, 155 Research Road, Quincy, FL 32351-5677

${ }^{7}$ Department of Entomology and Nematology, Mid Florida Research and Education Center, University of Florida, 2725 Binion Road, Apopka, FL 32703-8504

${ }^{8}$ Corresponding author. E-mail: ddtreadw@ufl.edu.
S ales of organic food reached $\$ 14.6$ billion in the United States in 2005 and of those sales, fruit and vegetable sales comprised $2.48 \%$ of the total U.S. agricultural market share [Organic Trade Association (OTA), 2006]. The organic fruit and vegetable category, including herbs, has comprised the largest single sector of the organic foods market for several years [ $43 \%$ in 2005 (OTA, 2006)]. When questioned about limitations to increasing market share of organic products, $52 \%$ of stakeholders to the organic foods industry responded that the lack of a dependable supply of certified organic ingredients such as thickeners, sweeteners, and flavorings was a limitation to increasing revenue (OTA, 2006). Consumer demand for fresh market organic produce combined with the increasing market share of "ready-to-eat" products indicates the potential for expansion of an organic culinary herb market.

Culinary herbs are herbaceous aromatic plants grown and marketed fresh or dried as transplants or cut and packaged (Simon, 1990). Additionally, herbs are sold wholesale for processing as ingredients in packaged and processed (ready-to-eat) foods. During the 10 -year period from 1995 to 2005 , total U.S. acreage of culinary and medicinal herbs, including greenhouse and field production, peaked in 2002 and $2003(25,782$ and 24,589 acres for 2002 and 2003 , respectively). According to the U.S. Department of Agriculture (USDA), $\approx 5250$ acres were in organic production of herbs in 2005 (USDA, 2006a). The most recent U.S. economic statistics were from 1999 when sales of fresh culinary herbs were reported to be $\$ 100$ million (USDA, 1999). Because herbs are a minor crop in most areas, data on acreage and sales of specific herb genera are not readily available from the National Agricultural Statistics Service (NASS), and furthermore, NASS data on U.S. production herbs no longer differentiate between herbs grown in the field or greenhouse. Some states have a substantial herb industry and report annual statistics on specific herbs. For instance, sales of fresh sweet basil in Hawaii were $\$ 5.5$ million in 2005 (USDA, 2006b). Categorically, fresh culinary herbs may be grouped with vegetables [including parsley (Carum petroselinum)]

\begin{tabular}{llll}
\hline $\begin{array}{l}\text { Units } \\
\begin{array}{l}\text { To convert U.S. to SI, } \\
\text { multiply by }\end{array}\end{array}$ & U.S. unit & SI unit & $\begin{array}{l}\text { To convert SI to U.S., } \\
\text { multiply by }\end{array}$ \\
\hline 10 & $\%$ & $\mathrm{~g} \cdot \mathrm{kg}^{-1}$ & 0.1 \\
0.4047 & $\mathrm{acre}(\mathrm{s})$ & $\mathrm{ha}$ & 2.4711 \\
2.5400 & inch $(\mathrm{es})$ & $\mathrm{cm}$ & 0.3937 \\
1.1209 & $\mathrm{lb} / \mathrm{acre}$ & $\mathrm{kg} \cdot \mathrm{ha}^{-1}$ & 0.8922 \\
1 & $\mathrm{ppm}$ & $\mathrm{mg} \cdot \mathrm{L}^{-1}$ & 1 \\
2.2417 & ton/acre & $\mathrm{mg} \cdot \mathrm{ha}^{-1}$ & 0.4461 \\
$\left({ }^{\circ} \mathrm{F}-32\right) \div 1.8$ & ${ }^{\circ} \mathrm{F}$ & ${ }^{\circ} \mathrm{C}$ & $\left(1.8 \times{ }^{\circ} \mathrm{C}\right)+32$
\end{tabular}


or with medicinal aromatic plants and spices [including lemongrass (Cymbopogon spp.)] as was the case in the recent global market report on organic agriculture (Willer and Yussefi, 2007). The lack of readily available statistical trends can be a limitation to growers who desire to know current market trends to aid in planning and marketing strategies.

Barriers to organic herb greenhouse production are high as a result of lack of available technical information and the low number of producers experienced in this area. Although a number of researchers have investigated cultural practices for culinary herb production in the field (Anwar et al., 2005; Chand et al., 2006; Davis, 1994; Kopsell et al., 2005; Loughrin and Kasperbauer, 2001; Rohloff et al., 2005), few have investigated herb production in the greenhouse (Chang et al., 2005; Copetta et al., 2006; Kopsell et al., 2005; Succop and Newman, 2004). Of these papers, only Succop and Newman (2004) reported using fertilizer sources approved for use in certified organic systems for greenhouse herb production. In addition, only Succop and Newman (2004) provided fertility recommendations for greenhousegrown basil. With this exception, tissue nutrient content thresholds for the developmental stages of herbs and recommendations for fertilizer source, rates, timing, and methods of application are currently not available for greenhouse production of culinary herbs in the published literature. The objective of this article is to review the literature on organic and conventional basil production that could be applied to nutrient management in organic greenhouse basil production.

\section{Production methods used in greenhouse herb production}

Planting and harvesting. Organic producers are required to use certified organic seed in production systems (USDA, 2007). After the 2002 National Organic Program debut, certified organic seeds were expensive and difficult to obtain as a result of the scarce supply. Currently, the number of popular commercial cultivars available as certified organic seed is increasing and, at least for some crops, seed prices have fallen to competitive levels. Fusarium wilt (Fusarium oxysporum f. sp. basilici)resistant basil 'Nufar' (Park Seed Co., Greenwood, SC) is one example of a popular cultivar that has recently become available as certified organic seed.

More than 50 species and forms of basil (Ocimum spp.) are available (Simon, 1995). Basil cultivars are available in a range of foliage colors (green to purple), flavors (lemon and cinnamon), and growth habits (bush type to small shrub). Basil seed should be placed no more than $0.5 \mathrm{~cm}$ below the surface of the media. Depending on cultivar, seed will germinate in media temperatures between 65 and $85^{\circ} \mathrm{F}$ and emerge in 8 to $14 \mathrm{~d}$. Basil is seeded in the greenhouse in May in New Hampshire (Kopsell et al., 2005), March in North Carolina (Davis, 1997), and December in Florida (Hochmuth et al., 2006). Plant spacing in hydroponic systems ranges from 5 -inch centers in California (Schoenstein, 1996) to 9-inch centers in Colorado (Succop and Newman, 2004).

Basil is ready for transplanting or for its first harvest of foliage 30 to 45 $\mathrm{d}$ after seeding. Basil can be harvested once sufficient stem length develops above the second to fourth pair of true leaves (Simon, 1995). Market preference for stem length usually dictates harvest schedule. Removal of the inflorescence during the production season is recommended for a dried leaf product, but if fresh leaves will be marketed, essential oils are greater if the plant is allowed to bloom (Simon, 1995). In research, basil crops were ended nearly $120 \mathrm{~d}$ after seeding (Hochmuth et al., 2006; Succop and Newman, 2004) or $\approx 20$ to $30 \mathrm{~d}$ after peak yields (Succop and Newman, 2004). Commercial producers will likely end after $90 \mathrm{~d}$ if environmental conditions or repeated cuttings from the same plant contribute to reduced plant growth or quality.

Planting systems. A number of planting systems and media have been examined for greenhouse organic production. Most trials have focused on organic vegetable transplant production; only one could be found that used culinary herbs (Succop and Newman, 2004). The systems and media used in experiments include rockwool slabs, perlite frames, peat- perlite-compost in pots (Succop and Newman, 2004), compost-peat in 72 -count trays (Clark and Cavigelli, 2005), compost-peat in Styrofoam transplant flat (Raviv et al., 1998), peat-perlite in 128-count trays (Russo, 2006), a range of peat-perlite mixes with supplemental fertilizer and media amendments in bags (Rippy et al., 2004), and a peat-perlite-filled trough system (Hochmuth et al., 2006).

Media. Media in organic production must be free of synthetically derived starter fertilizers or wetting agents; however, these components are available in approved organic forms. Starter fertilizers are typically dehydrated and pelletized animal waste or animal byproducts (e.g., feathermeal). Saponin, a derivative of the yucca plant ( (ucca spp.), is commonly used as a wetting agent. A summary of allowable media ingredients and suggestions for media formulations is provided by Kuepper and Adam (2003). Typical planting media recipes contain a mixture of peat, perlite, and vermiculite as the basic planting substrate. In addition, compost may comprise $25 \%$ to $50 \%$ of the volume of the substrate material, but when greater than $50 \%$ compost is used, yield decline has been reported (Clark and Cavigelli, 2005). Dolomite, kelp meal, and soft rock phosphate are added to this mixture to adjust the $\mathrm{pH}$, provide micronutrients and nitrogen, and provide a slow release of phosphorus.

Ideal media for basil production should be composed of particles large enough to allow adequate pore space for microbial and root respiration. If media is too fine, increased water retention may inhibit nitrification. According to Raviv et al. (1998), media should have adequate free air space, high water content, and high cation exchange capacity. Poor nutrition and unsuitable media are reasons for plant nonuniformity and mortality. Plants that are slow to mature or have reduced growth negatively impact the grower's economic return. A greenhouse experiment compared the main plot effects of two types of fertilizer with similar nutrient content (a modified Hoagland's solution made from commercially available synthetic nutrients and a commercially available organic nutrient solution) and subplot effects of three types of hydroponic media (rockwool 
slabs, perlite frames, and a peat-perlite-compost blend) on basil production (Succop and Newman, 2004). Basil cuttings $\approx 3$ inches in length were harvested weekly from each stem. Basil responded differently to fertilizer source and planting media. In perlite media, total basil yield was $22 \%$ and $100 \%$ greater in organic fertilizer compared with synthetic fertilizer for trail years 1 and 2 , respectively. However, plants grown in rockwool were $17 \%$ and $46 \%$ more productive with synthetic fertilizer than organic fertilizer in years $l$ and 2 , respectively. The authors hypothesized that the high water-holding capacity and low aeration of rockwool may have contributed to a decline in microbial activity to the reduced yield in organically fertilized basil compared with synthetic fertilizer. Fertility source had no effect on total basil yield when produced in the peatperlite-compost media.

Peat moss is a desirable media substrate, but there are several disadvantages. Peat is considered a major sink for the earth's carbon dioxide. Although peat is harvested from several areas worldwide, the quality of sphagnum moss from Canadian peat bogs is considered superior as a result of its high cation exchange capacity and beneficial physical properties. However, it can take decades to renew a Canadian bog once harvested, and shipping peat to nontemperate climates can be prohibitively expensive. Compared with compost-based media, peat has also been associated with a loss of suppressiveness to pythium damping-off (Pythium ultimum) attributable mainly to a shift in biocontrol agents (Hoitink and Boehm, 1999). Reuveni et al. (2002) recommended sterilizing peat-based media to eradicate minor pathogens before basil seeding. Although peat and vermiculite are allowed, concerns about the future availability of sphagnum peat from Canadian sources (Raviv et al., 1998) and asbestos content of vermiculite from certain areas such as Montana (Peipins et al., 2003) have limited use of these products in organic systems.

COMPOST AS A MEDIA AMENDMENT. Compost is typically used in field production but can also be used as a bulking agent in growth media or as a sole ingredient. In response to concerns over the high costs and long-term sustainability of peat-based media, growers are seeking alternatives such as compost (from many sources) to reduce reliance on peat materials. Compost composition varies widely among studies because of the wide variety of suitable raw materials.

Compost manufacture in organic production is strictly defined to minimize the occurrence of human pathogens (USDA, 2002). The National Organic Standards require raw composting materials to have a carbon-to-nitrogen ratio between 25:1 and 40:1. Temperature during composting must be maintained between 131 and $170{ }^{\circ} \mathrm{F}$ for $3 \mathrm{~d}$ for an in-vessel or static aerated pile system or for $15 \mathrm{~d}$ for windrow composting systems. Otherwise, the material must be managed according to handling regulations for raw manure. According to organic production standards, raw manure must be applied to soil $90 \mathrm{~d}$ in advance of crops with harvested portions that do not touch the soil and $120 \mathrm{~d}$ in advance of harvested portions that do touch the soil.

Many studies have been conducted on the use of compost as a media supplement in greenhouse production, but these studies have focused mainly on compost as a substitute for other substrates and not for the objective of providing nutrients (Ozores-Hampton and Vavrina, 2002; Raviv et al., 1998; Sterrett, 2001). Overall, these studies reported improved yield with the addition of or sole reliance on compost as a planting substrate compared with substrates without compost. The fine particle size of compost is attributed to increased bulk density and higher water tension and therefore increased water retention compared with peat. When compost is used as a substrate, irrigation regimes will need to be adjusted to reduce the amount or frequency of water applied. This can be an advantage for growers who desire to minimize total water use because the total amount of water applied to planting media containing compost will be less than media without compost. One additional benefit of using compost in basil production is to reduce the incidence of Fusarium wilt, a major production concern of greenhouse basil (Wick and Haviland, 1992). Compost has been cited as a possible disease-suppressive material in basil production (Raviv et al., 1998; Reuveni et al., 2002), but some formulations have been demonstrated to have herbicidal properties on small-seeded annual weeds (OzoresHampton et al., 2001). Specific phytotoxic effects of compost on basil seeds have not been reported. Use of compost as a bulking agent to reduce reliance on peat-based substrates should include estimates of nutrient contributions as well as verification that germination and root growth of the crop will not be negatively affected.

\section{Nutrient management}

Nutrient sources. In organic production systems, two main groups of resources can be used to supply nutrients: plant- and animal-based amendments and standardized commercially available products. Use of animal- and plant-based amendments from resources close to the production area exemplifies one of the major tenets of organic philosophy by taking advantage of local renewable resources. However, it is challenging to develop a standardized nutrient management program as a result of the highly variable nature of these materials. Historically, most of the replicated trials presented in the literature used locally available resources.

Mined sources of macronutrients [nitrogen $(\mathrm{N})$, phosphorus $(\mathrm{P})$, potassium $(\mathrm{K})$, calcium $(\mathrm{Ca})$, and magnesium] are allowed in organic production. A maximum of $20 \%$ of the crop's total $\mathrm{N}$ requirement can be supplied by mined sodium nitrate $\left(\mathrm{NaNO}_{3}\right)$. Sodium nitrate is prohibited by the European Union and Japanese organic standards, and organic produce grown in the United States with $\mathrm{NaNO}_{3}$ cannot be sold organically in those countries. It is uncertain if the USDA National Organic Program will continue to allow its use in U.S. production systems. As a result of the scarcity of naturally available micronutrients, synthetically derived micronutrients (that have been chemically altered by a manufacturing process) are allowed if the producer can document a deficiency through soil or plant tissue analysis reports, although in a shortseason crop such as basil, this can be problematic. 
Recent introductions of commercially available fertilizers with guaranteed $\mathrm{N}-\mathrm{P}-\mathrm{K}$ analyses and approved for use in organic systems have increased fertilizer options for producers. Although actual formulations are proprietary, these materials are dehydrated and pelletized blends of animal wastes or animal byproducts supplemented by dolomitic limestone, potassium magnesium sulfate, and other naturally derived components. To date, these granular animal-based products have been tested minimally in research trials (Hochmuth et al., 2006) despite their widespread adoption by growers.

Fish and seaweed emulsions and meals are available in formulations approved for use in organic production. Some commercial products contain prohibited inert ingredients, so it is important to obtain an approved product. Fish-based products provide a low concentration of $\mathrm{N}$ (typically 10 to $30 \mathrm{~g} \cdot \mathrm{kg}^{-1}$ material) and therefore are often applied at much higher rates (Russo, 2005, 2006). In at least one trial, peat-based media amended with a $40 \mathrm{~g} \cdot \mathrm{kg}^{-1}$ mixture of fish emulsion improved suppression of rhizoctonia (Rhizoctonia solani) and pythium damping-off of radish (Raphanus sativus) and cucumber (Cucumis sativus) seedlings (Abbasi et al., 2004). Kelp (Ascophyllum nodosum) and other seaweeds provide a good source of micronutrients as well as phytohormones such as cytokinin (Zhang and Ervin, 2004). These products are available as liquid or granular formulations. They are mixed preplant applied as a soil drench, as a foliar spray, and through drip irrigation lines. Although the economics of using emulsions or meals in basil production have not been formally examined, these products can be expensive to ship in liquid form and therefore may be prohibitive in large operations.

In organic greenhouse production, fertilizer sources are often assessed based on the timing of $\mathrm{N}$ release relative to crop demand. As a result of the high cost of laboratory analysis for $\mathrm{N}$ content in media or solution, $\mathrm{N}$ release rates are often measured indirectly through plant growth parameters such as height and yield (Rippy et al., 2004; Russo, 2006; Succop and Newman, 2004) or $\mathrm{N}$ accumulation in leaf tissues
(Montagu and Goh, 1990; Rippy et al., 2004) and fruit (Montagu and Goh, 1990).

The type of fertilizer used can affect herb quality. For example, Anwar et al. (2005) observed the foliage yield, essential oil content, and oil yield in field-grown basil $(O$. basilicum 'Vikas Sudha') foliage was greatest when vermicompost (5 $\mathrm{mg} \cdot \mathrm{ha}^{-1}$ ) plus conventional fertilizer $\left\{50 \mathrm{~kg} \cdot \mathrm{ha}^{-1} \mathrm{~N}, 25 \mathrm{~kg} \cdot \mathrm{ha}^{-1} \mathrm{P}\right.$, and $25 \mathrm{~kg} \cdot \mathrm{ha}^{-1} \mathrm{~K}$ applied as urea $\left[\left(\mathrm{NH}_{2}\right)_{2} \mathrm{CO}\right]$, single superphosphate $\left[\mathrm{Ca}\left(\mathrm{H}_{2} \mathrm{PO}_{4}\right) 2 \cdot \mathrm{H}_{2} \mathrm{O}\right]$, and muriate of potash $(\mathrm{KCl})$, respectively $\}$ compared with five other organic or conventional fertilizer sources. In greenhouse basil, a proprietary organic fertilizer made of poultry litter, kelp, and soft rock phosphate applied in liquid formulation provided 369 $\mathrm{mg} \cdot \mathrm{L}^{-1} \mathrm{~N}, 78 \mathrm{mg} \cdot \mathrm{L}^{-1} \mathrm{P}$, and 280 $\mathrm{mg} \cdot \mathrm{L}^{-1} \mathrm{~K}$ similar to conventional fertilizer $\left(364 \mathrm{mg} \cdot \mathrm{L}^{-1} \mathrm{~N}, 78 \mathrm{mg} \cdot \mathrm{L}^{-1} \mathrm{P}\right.$, and $308 \mathrm{mg} \cdot \mathrm{L}^{-1} \mathrm{~K}$ ), but taste test panelists determined organically fertilized basil tasted differently than conventionally fertilized basil (Succop and Newman, 2004).

Nitrogen mineralization. The most challenging aspect of nutrient management in organic greenhouse systems is synchronizing the mineralization of $\mathrm{N}$ with the crop's nitrogen demand. Although animal-based meals, emulsions, and manures have been used in organic farming for many years, little data on $\mathrm{N}$ mineralization rates have been reported. Organic N forms require degradation of proteins by microbes before plant uptake. Therefore, microbial activity is influenced by environmental factors, including temperature and moisture of the media substrate as well as the biochemical composition of the organic fertilizers. Variability of $\mathrm{N}$ release rates have been attributed to environmental conditions in the greenhouse (Kraus et al., 2000 ) as well as physical and chemical characteristics of the media and fertilizer source (Montagu and Goh, 1990; Rippy et al., 2004). As a result of the many interacting factors, $\mathrm{N}$ release is difficult to predict.

In a trial comparing two organic fertilizers (chicken manurebased compost and a mixture of bone meal plus blood meal) with two synthetic fertilizers, ammonium sulfate $\left[\left(\mathrm{NH}_{4}\right)_{2} \mathrm{SO}_{4}\right]$ and potassium nitrate
$\left(\mathrm{KNO}_{3}\right)$, on greenhouse tomato (Solanum lycopersicum), foliar $\mathrm{N}$ in plants receiving the blood plus bone meal treatment increased linearly with increasing amendment rate just as the synthetic fertilizers (Montagu and Goh, 1990). The authors attributed the decline in foliar and fruit $\mathrm{N}$ and tomato yield in the compost treatment to the large particle size of the compost, the age of the material, and the slow rate of mineralization of $\mathrm{N}$ resulting from a high C:N ratio (37:1). The low C:N ratio of the blood plus bone meal (5:1) combined with the fine particle size of blood meal may have contributed to a more rapid mineralization of organic $\mathrm{N}$ compared with compost.

To provide a consistent source of $\mathrm{N}$ over the course of production, one possible solution would be to combine amendments with slow $\mathrm{N}$ release patterns with amendments that have more soluble and readily available forms of organic N. Nitrogen mineralization from organic fertilizers with high $\mathrm{N}$ content was examined in an incubation experiment by Hartz and Johnstone (2006). It was observed that for seabird guano, hydrolyzed fish powder, feather meal, and blood meal, the vast majority of $\mathrm{N}$ was mineralized during the first $14 \mathrm{~d}$. The rapid mineralization and the high cost of these materials suggested that the most appropriate use is to provide a quick supply of $\mathrm{N}$ during critical periods of crop development as a supplement to the slower $\mathrm{N}$ release of more complex organic amendments such as compost. Patterns of nutrient acquisition during greenhouse basil production are not known, although demand for nutrients may be related to air temperature during basil production. Basil foliar biomass, dry matter content, and volatile oil content were greatest when temperatures remained constant at $25{ }^{\circ} \mathrm{C}$ during 3 weeks of production compared with constant temperatures of 15 or $30{ }^{\circ} \mathrm{C}$ (Chang et al., 2005).

Clark and Cavigelli (2005) examined compost as a source of slow-release nutrients in organic lettuce (Lactuca sativa var. longifolia) and tatsoi (Brassica rapa var. rosularis) production. Compost made from preconsumer food residuals and compost from horse bedding were similar 
in total $\mathrm{N}$ concentration, carbon-tonitrogen ratios, and bulk densities but performed very differently for lettuce production. Mineralization potential of composts increased when $\mathrm{C}: \mathrm{N}$ ratios were 25:1 and increased rapidly when C:N ratios were 20:1 or less. Lettuce and tatsoi production in compost made from food residuals was similar to production with the commercial peat-based and synthetically fertilized media. However, crops grown in compost made from horse bedding failed to produce marketable yields. High salinity and inhibition of $\mathrm{N}$ mineralization in this particular compost made from horse bedding most likely inhibited growth, despite the successful use of horse compost in other applications (Zubillaga and Lavado, 2006).

Compost maturity can be tested with indices such as Solvita test (Woods End Research Laboratory, Mt. Vernon, ME). This test assigns a value to the material based on carbon dioxide and ammonia $\left(\mathrm{NH}_{3}\right)$ emissions and is useful for estimating composting maturity on farms (Changa et al., 2003). If organic materials are completely composted before amending media, very little ammonium $\left(\mathrm{NH}_{4}^{+}\right)$and $\mathrm{NH}_{3}$ should be present. Additional factors, such as electrical conductivity (EC) and $\mathrm{pH}$ should be considered before using compost as a media supplement. Additions of animal-based manure compost to planting media can increase the EC and $\mathrm{pH}$ to levels greater than conventional fertilizers (Rippy et al., 2004) and can be excessive for adequate plant growth (Clark and Cavigelli, 2005). Because the availability of some nutrients ( $P$, iron, and manganese) may be limited at $\mathrm{pH}$ greater than 6.4 resulting in poor crop development and reduced yield (Nelson, 1998), compost should be tested before amending media. In a commercial production system, media $\mathrm{pH}$ can be reduced with additional of elemental sulfur to offset anticipated increases in $\mathrm{pH}$ resulting from organic fertilizer. The process of acidification is mediated by microbes and can take several weeks to several months before a stable and reduced $\mathrm{pH}$ is achieved.

Nutrient release patterns are sometimes confounded by mediafertilizer interactions that alter media $\mathrm{pH}$ and EC levels. Interactions of media and nutrient sources on nutritional status of plant foliage or fruit have been observed (Succop and Newman, 2004) but not always so (Rippy et al., 2004). In organic greenhouse basil production, Succop and Newman (2004) attributed differences in $\mathrm{N}$ mineralization from organic sources to differences in the physical properties among the media tested. The high porosity and consequent availability of oxygen may have facilitated decomposition of the organic fertilizer in perlite compared with rockwool and peat-perlitecompost substrates. Basil yields with conventional synthetic fertilizer were similar among all media tested, whereas yields from organic sources were highest in perlite and similar to peat-perlite-compost compared with rockwool.

\section{Conclusions}

The National Organic Standards lack regulatory language that is specific to organic greenhouse production. Rather, certification agencies refer to field crop production standards written for greenhouse crops. The National Organic Standards Board is actively working on this issue now to determine if additional regulatory language is necessary to define crop production standards for greenhouse crops or if the existing language is sufficient. Although it is uncertain whether hydroponic systems (nutrient solution only) will remain eligible for organic certification, all crop transplants and starts are required to be produced using USDA National Organic Program standards. To this end, the number of variables involved in vegetable transplant and herb production are large, and additional investigations are necessary before research-based recommendations can be made.

Reliance on organic sources of fertilizer can be difficult in greenhouse systems as a result of their highly variable nature and difficulty in synchronizing $\mathrm{N}$ mineralization with crop demand. An increasing number of commercial fertilizer products are becoming available for organic systems that could be used to supplement slow-release organic materials to supply more rapidly soluble forms of N. Specific to nutrient management, the major issues in organic greenhouse production are to find methods to optimize synchrony between nutrient mineralization and crop demand; to provide the full compliment of crop nutrients without oversupplying a particular nutrient; and to identify physical, chemical, and biological factors that affect nutrient mineralization for a variety of potting media. Therefore, the development of plant and media diagnostic tests to predict $\mathrm{N}$ availability would be beneficial to producers. Finally, the relationship between nutrient source and crop quality should continue to be explored.

\section{Literature cited}

Abbasi, P.A., K.L. Conn, and G. Lazarovits. 2004. Suppression of rhizoctonia and pythium damping-off of radish and cucumber seedlings by addition of fish emulsion to peat mix or soil. Can. J. Plant Pathol. 26:177-187.

Anwar, M., D.D. Patra, S. Chand, K. Alpesh, A.A. Naqvi, and S.P.S. Khanuja. 2005. Effect of organic manures and inorganic fertilizer on growth, herb and oil yield, nutrient accumulation and oil quality of French basil. Commun. Soil Sci. Plant Anal. 36:1737-1746.

Chand, S., M. Anwar, and D.D. Patra. 2006. Influence of long-term application of organic and inorganic fertilizer to build up soil fertility and nutrient uptake in min-mustard cropping sequence. Commun. Soil Sci. Plant Anal. 37:63-76.

Chang, X., P.G. Alderson, and C.J. Wright. 2005. Effect of temperature integration on the growth and volatile oil content of basil (Ocimum basilicum L.). J. Hort. Sci. Biotechnol. 80:593-598.

Changa, C.M., P. Wang, M.E. Watson, H.A.J. Hoitink, and F.C. Michel, Jr. 2003. Assessment of the reliability of a commercial maturity test for composted manures. Compost Sci. Util. 11:125-143.

Clark, S. and M. Cavigelli. 2005. Suitability of composts as potting media for production of organic vegetable transplants. Compost Sci. Util. 13:150-156.

Copetta, A., G. Lingua, and G. Berta. 2006. Effects of three AM fungi on growth, distribution of glandular hairs, and essential oil production in Ocimum basilicum L. var. Genovese. Mycorrhiza 16:485-494.

Davis, J.M. 1994. Comparison of mulches for fresh-market basil production. HortScience 29:267-268.

Davis, J.M. 1997. Basil. North Carolina Coop. Ext. Serv. Bul. HIL125. 14 Feb. 
2007. <http://www.ces.ncsu.edu/ depts/hort/hil/hil-125.html>.

Hartz, T.K. and P.R. Johnstone. 2006. Nitrogen availability from high-nitrogen containing organic fertilizers. HortTechnology 16:39-42.

Hochmuth, G.J., R.C. Hochmuth, R.K. Sprenkel, E.H. Simonne, D.D. Treadwell, T.W. Olczyk, and Y.C. Li. 2006. Adopting new plasticulture techniques to grow organic herbs in Florida greenhouses. Proc. 33rd National Agricultural Plastics Congress, San Antonio, TX, 2-5 Nov. 2006. Amer. Soc. Plasticulture, State College, PA. p. 11-15.

Hoitink, H.A.J. and M.J. Boehm. 1999. Biocontrol within the context of soil microbial communities: A substratedependant phenomenon. Annu. Rev. Phytopathol. 37:427-446.

Kopsell, D.A., D.E. Kopsell, and J. Curran-Celentano. 2005. Carotenoid and chlorophyll pigments in sweet basil grown in the field and greenhouse. HortScience 40:1230-1233.

Kraus, H.T., R.L. Mikkelsen, and S.L. Warren. 2000. Container substrate temperatures affect mineralization of composts. HortScience 35:16-18.

Kuepper, G. and K. Adam. 2003. Organic potting mixes for certified production. 5 Mar. 2007. <http://attra.ncat.org/attrapub/potmix.html>.

Loughrin, J.H. and M.J. Kasperbauer. 2001. Light reflected from colored mulches affects aroma and phenol content of sweet basil (Ocimum basilicum L.) leaves. J. Agr. Food Chem. 49:1331-1335.

Montagu, K.D. and K.M. Goh. 1990. Effects of forms and rates of organic and inorganic nitrogen fertilizers on the yield and some quality indices of tomatoes (Lycopersicon esculentum Miller). N. Z. J. Crop Hortic. Sci. 18:31-37.

Nelson, P.V. 1998. Greenhouse operation and management. 5th ed. Prentice Hall, Englewood Cliffs, NJ.

Organic Trade Association. 2006. The Organic Trade Association's 2006 manufacturer's survey. 8 Feb. 2007. <http:// www.ota.com/pics/documents/short $\%$ 20overview\%20MMS.pdf>.

Ozores-Hampton, M. and C.S. Vavrina. 2002. Worm castings: An alternative to sphagnum peat moss inorganic (Lycopersicon esculentum Mill.) transplant production, p. 105-113. In: F.C. Michel, R.F. Rynk, and H.A.J. Hoitink (eds.). Proc. 2002 Intl. Compost Symp.: Composting and Compost Utilization. JG Press, Emmaus, PA.

Ozores-Hampton, M.P., T.A. Obreza, and P.J. Stoffella. 2001. Weed control in vegetable crops with composted organic mulches, p. 275-286. In: P.J. Stoffella and B.A. Kahn (eds.). Compost utilization in horticultural cropping systems. Lewis Publ., Boca Raton, FL.

Peipins, L.A., M. Lewin, S. Campolucci, J.A. Lybarger, A. Miller, D. Middleton, C. Weis, M. Spence, B. Black, and V. Kapil. 2003. Radiographic abnormalities and exposure to asbestos-contaminated vermiculite in the community of Libby, Montana, USA. Environ. Health Perspect. 111:1753-1759.

Raviv, M., R. Reuveni, and B.Z. Zaidman. 1998. Improved medium for organic transplants. Biol. Agr. Hort. 16: 53-64.

Reuveni, R., M. Raviv, A. Krasnovsky, L. Freiman, S. Medina, A. Bar, and D. Orion. 2002. Compost induces protection against Fusarium oxysporum in sweet basil. Crop Prot. 21:583-587.

Rippy, J.F.M., M.M. Peet, F.J. Louws, P.V. Nelson, D.B. Orr, and K.A. Sorensen. 2004. Plant development and harvest yields or greenhouse tomatoes in six growing systems. HortScience 39:223-229.

Rohloff, J., S. Dragland, R. Mordal, and T. Iverson. 2005. Effect of harvest time and drying method on biomass production, essential oil yield, and quality of peppermint (Mentha $\times$ piperita L.). J. Agr. Food Chem. 53:4143-4148.

Russo, V.M. 2005. Organic vegetable transplant production. HortScience 40:623-628.

Russo, V.M. 2006. Biological amendment, fertilizer rate and irrigation frequency for organic bell pepper transplant production. HortScience 41:1402-1407.

Schoenstein, G. 1996. Hydro-organics: Growing basil during the of-season. Small Farm Today 13:39-42.

Simon, J.E. 1990. Essential oils and culinary herbs, p. 484-489. In: J. Janick and J.E. Simon (eds.). Advances in new crops. Timber Press, Portland, OR.

Simon, J.E. 1995. Sweet basil: A production guide. Purdue Coop. Ext. Serv. Res. Bul. HO-189. 2 Mar. 2007. <http:// www.hort.purdue.edu/newcrop/ CropFactSheets/basil.html>.
Sterrett, S.B. 2001. Composts as horticultural substrates for vegetable transplant production, p. 95-119. In: P.J. Stofella and B.A. Kahn (eds.). Compost utilization in horticultural cropping systems. Lewis Publ., Boca Raton, FL.

Succop, C.E. and S.E. Newman. 2004. Organic fertilization of fresh market sweet basil in a greenhouse. HortTechnology $14: 235-239$.

U.S. Department of Agriculture. 1999. Greenhouse produced food crops by state: 1998. 6 Feb. 2007. <http:// www.nass.usda.gov/census/census97/ horticulture/table37.pdf>.

U. S. Department of Agriculture. 2002. The National Organic Program. Production and handling-Regulatory text. 6 Feb. 2007. <http://www.ams.usda. gov/NOP/NOP/standards/ProdHand Reg.html>.

U.S. Department of Agriculture. 2006a. Data sets: Organic production. Table 12. Certified organic herbs, nursery and greenhouse. 6 Feb. 2007. <http:// www.ers.usda.gov/Data/organic/>.

U.S. Department of Agriculture. 2006b. Hawaii herbs: 26 July 2006. 27 Feb. 2007. <http://www.nass.usda.gov/hi/ vegetble/herb.pdf $>$.

U.S. Department of Agriculture. 2007. The National Organic Program. 6 Feb. 2007. <http://www.ams.usda.gov/ nop/indexIE.htm $>$.

Wick, R.L. and P. Haviland. 1992. Occurrence of fusarium wilt of basil in the United States. Plant Dis. 76:323. (Abstr.).

Willer, H. and M. Yussefi. 2007. Organic farming worldwide 2007: Overview and main statistics, p. 9-16. In: H. Willer and M. Yussefi (eds.). The world of organic agriculture: Statistics and emerging trends 2007, 9th ed. Intl. Federations of Organic Agr. Movements, Bonn, Germany; and Res. Inst. of Organic Agr., Frick, Switzerland.

Zhang, X.Z. and E.H. Ervin. 2004. Cytokinin-containing seaweed and humic acid extracts associated with creeping bentgrass leaf cytokinins and drought resistance. Crop Sci. 44:1737-1745.

Zubillaga, M.S. and R.S. Lavado. 2006. Phytotoxicity of biosolids compost at different degrees of maturity compared to biosolids and animal manures. Compost Sci. Util. 14:267-270. 